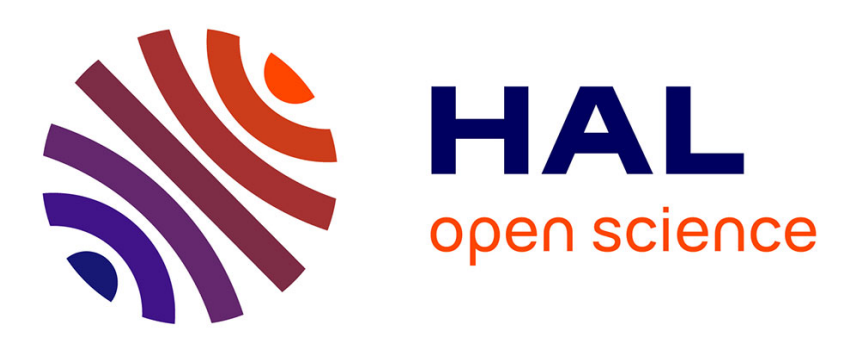

\title{
Use of applied theatre in health research dissemination and data validation: a pilot study from South Africa
}

\author{
Maria Stuttaford, Claudette Bryanston, Gillian Lewando Hundt, Myles
}

Connor, Margaret Thorogood, Stephen Tollman

\section{To cite this version:}

Maria Stuttaford, Claudette Bryanston, Gillian Lewando Hundt, Myles Connor, Margaret Thorogood, et al.. Use of applied theatre in health research dissemination and data validation: a pilot study from South Africa. Health:, 2006, 10 (1), pp.31-45. 10.1177/1363459306058985 . hal-00571418

\section{HAL Id: hal-00571418 https://hal.science/hal-00571418}

Submitted on 1 Mar 2011

HAL is a multi-disciplinary open access archive for the deposit and dissemination of scientific research documents, whether they are published or not. The documents may come from teaching and research institutions in France or abroad, or from public or private research centers.
L'archive ouverte pluridisciplinaire HAL, est destinée au dépôt et à la diffusion de documents scientifiques de niveau recherche, publiés ou non, émanant des établissements d'enseignement et de recherche français ou étrangers, des laboratoires publics ou privés. 


\title{
Use of applied theatre in health research dissemination and data validation: a pilot study from South Africa
}

DOI: $10.1177 / 1363459306058985$

1363-4593; Vol 10(1): 31-45

\author{
Maria Stuttaford, Claudette Bryanston, Gillian \\ Lewando Hundt, Myles Connor, Margaret \\ Thorogood \& Stephen Tollman \\ University of St Andrews, UK, University of Warwick, UK, \\ University of Warwick, UK, University of the Witwatersrand, South \\ Africa, University of Warwick, UK, University of the \\ Witwatersrand, South Africa
}

ABSTRACT This article reports on a pilot study of the use of applied theatre in the dissemination of health research findings and validation of data. The study took place in South Africa, as part of the Southern Africa Stroke Prevention Initiative (SASPI) and was based at the University/Medical Research Council Rural Public Health and Health Transitions Research Unit (also known as the Agincourt Unit). The aim of SASPI was to investigate the prevalence of stroke and understand the social context of stroke. It was decided to use an applied theatre approach for validating the data and disseminating findings from the anthropological component of the study. The pilot study found that applied theatre worked better in smaller community groups. It allowed data validation and it elicited ideas for future interventions resulting from the health research findings. Evaluation methods of the impact of applied theatre as a vehicle for the dissemination and communication of research findings require further development.

KEYWORDS dissemination; stroke; South Africa; theatre; validation

ADDRESS Maria Stuttaford, School of Geography \& Geosciences, University of St Andrews, North Street, St Andrews, Fife KY16 9AL, UK. [Tel: + 44 (0)1334 46 3941; fax: + 44 (0)1334 46 3949; e-mail: maria.stuttaford@ st-andrews.ac.uk]

ACKNOWLEDGEMEnTS The research was undertaken with support from a Wellcome Trust grant (Ref 06476/Z/01/Z). The study would not have been possible without the co-operation of the many respondents that agreed to 
participate and gave their time to teach us about their lives. The authors would also like to acknowledge the stimulating discussions held with members of the Applied Theatre Research Development Group, Institute of Health, University of Warwick, especially Rose Ruddick, as well as the comments of the three anonymous reviewers.

\section{Introduction}

The focus of this article is the use of applied theatre for the validation of data and dissemination of health research findings. The findings from a multidisciplinary study were complex and the research team was committed to communicating findings back to participants. At the same time the team wanted to check data validity by returning to respondents and presenting research material. The article begins by reviewing key literature on applied theatre and defines what is meant by applied theatre as used in this pilot study. It then provides an outline of the anthropological component of the Southern African Stroke Prevention Initiative (SASPI), the methods used and key findings that were reported through the applied theatre. The development of Xiseveseve (coming together to share) is described and impressions of the fieldworkers and 'spect-actors' (a term introduced by Augusto Boal [1979] to describe directed participation by members of an audience) are presented. The article concludes with a consideration of the further use of applied theatre in data validation and health research dissemination.

\section{Using applied theatre for research dissemination and validation}

Theatre is frequently used in health promotion, education and the training of health professionals (Fenn, 2003; Public Health News, 2003; The Drum Beat, 2004; The National Network for Arts in Health, 2004). Role-play and other drama strategies have been used to replicate the work situations of health professionals to support training and develop customer care. Specialist art therapists draw from the visual and dramatic arts focusing on participation within a therapeutic setting as a means of supporting healing. However, the focus here is actually on using theatre in the validation and dissemination of health research findings.

The research team used applied theatre in that the work was performed to an invited public audience. This work was not concerned with educational drama, often referred to as process drama. Such work takes place within a closed workshop, the participants are the only audience and the aim of the work is almost exclusively educational.

Applied theatre can be described as theatre that is created for a specific need. It usually takes place in non-theatre spaces and is motivated by a desire to generate social change. Many of the most innovative theatre 
companies are driven by the desire to create theatre for those who might not usually attend mainstream theatres or art centres. Such theatre happens in a wide variety of settings and communities, from formal institutions such as schools, prisons and hospitals to informal spaces such as community centres in deprived urban areas and rural communities. Theatre has no borders and finds its forms in the existing cultural expression of the communities that create it. It offers the means of creating an analysis of the economic, cultural and social conditions, particularly of the very poor.

Theatre can be created for specific groups such as the elderly, pre-school children or people with physical or learning difficulties. Some of the most exciting theatre stems from the rich diversity of the multi-cultural communities working in the arts in the UK. Perhaps the most influential British work in this field has been the pioneering work of Theatre in Education. This type of theatre can be called 'applied' as it is created specifically to support the education of young people and children in schools. It was developed in England in the early 1950s. The first Theatre-in-Education company produced work from the Belgrade Theatre in Coventry and provided a free service to all the schools of the city until the early 1990s.

In recent years, the term 'applied theatre' is being used in UK academia to define theatre that is not accurately described by the umbrella term of Community Theatre or Theatre-in-Education. It has come to be the term used to describe theatre that has been created for an explicit purpose. For example, in this pilot project that purpose was to disseminate research findings in a particular place to a specific group of people. Applied theatre has a growing place in a complex world where its power as a medium that offers clarification is unique, not only using the spoken word but also the erudition of signed meaning through images and the universal language of physical theatre.

Several advantages have been put forward for using applied theatre in dissemination of research findings. The live performance of findings serves to concretize, rather than abstract, the experiences of research participants (Paget, 1990). Applied theatre presents research in a way where there is audience engagement with research material and therefore there is greater potential for transforming social understanding than with textual presentation (Gray et al., 2000). In this way it challenges the academic privileging of written text (Paget, 1990). Often, but not always, the theatre is created through composites as focal points for audience members to discuss their own experiences of topics and is often used to gain access to the 'closed world' of the participants. It is 'a means to give insight into the lives of those who have become marginalised and disempowered through their relationships with health' (Mienczakowski, 1997: 163). It fits the critical social science approach that research should empower participants to change the context in which they operate or the way they behave.

The final contribution of applied theatre is towards validity. One way of assessing validity is by returning to respondents and presenting research 
material to them. This not only guards against researcher bias and improves credibility (Lincoln and Guba, 1985) but also demonstrates that the researcher values their contribution. Applied theatre has an advantage over textual reporting in terms of validity because it sustains connections with emotions and the sensory experience (Mienczakowski, 1997; Paget, 1990; Gray et al., 2000). It can also validate data through post-performance feedback (Gray et al., 2000)

Various approaches to developing an applied theatre production have been documented (Mienczakowski et al., 1996; Goldstein, 2001; Saldaña, 2003). For example, in 2003, Making Research Count commissioned a production from Geese Theatre called Trauma (Making Research Count, 2003). This production utilized material from several workshops held during 2002 with public sector and voluntary sector agencies examining research and experience of domestic violence and mental health practitioners to develop a script, which was then performed by professional actors to practitioners. An alternative approach was taken by Liebling (2004) to feed back her research on Ugandan women's experiences of violence, rape and torture during the civil war in that country. A community-based drama group presented the research at a local community workshop.

Although the diversity of approaches has been documented, less has been reported on potential shortcomings. A key issue that arose in this pilot study was that of ethics. Saldaña (1998) raises questions about who should perform the theatre and of what text to select for inclusion, avoiding simply selecting text for 'dramatic impact'. Disclosing the identity of people also requires consideration. For example, research participants may or may not perform their own data and anonymity must be protected where that has been guaranteed. Cornwall (1997) points out that artistic forms need to be used with caution as they may serve to reinforce an existing order. Artistic forms may also be appropriated by the powerful and used as an instrument of oppression. Malunga (2000) explored ethnic dances on the copper mines in South Africa between 1920 and 1960 and shows how traditional dances were supported by mine management as a means of social and labour control in so far as it kept workers 'constructively' engaged at the weekends.

Adopting the principles of participatory research will assist in addressing these potential shortcomings. Cornwall (1997: 23) provides an overview of participatory uses of the arts in development and describes how participatory performance is characterized by 'working with and from people's own realities and using their own modes of expression. Local people replace outsider scriptwriters, illustrators, editors, directors and actors and become active participants in creating and exploring solutions to real-life dilemmas.' Theatre enables us to examine the human condition from the outside but close to the real experience. An audience is able to examine the world through a dramatic lens that both heightens and clarifies its issues. Theatre tells a story. If the story depicts a familiar world, the shared experience of the audience is enhanced. If the line between the audience and the players 
is blurred and the audience is invited to cross that line and tell his or her version of the story with the players, then the members of the audience acquire a certain authority. They are the experts. This authority is possible when the audience can draw upon their expertise relating to the presented events. Theatre presents stories as dramatic problems; these problems can be handed to the audience. Participatory theatre is often a core element in Theatre-in-Education and can take many forms. The most effective of these have been appropriated from Augusto Boal's interventionist theatre. His (1979) work developing Teatro do Oprimido (Theatre of the Oppressed), as set out in his seminal text, gained international recognition as a theoretical model of revolutionary theatre. This approach has been described also as Forum Theatre.

Boal connects collective social narratives of everyday oppression (Mienczakowski, 1997). The audience in Boal's (1992: 28) theatre are known as spect-actors:

In Forum Theatre at no time should an idea be imposed. Forum Theatre does not preach, it is not dogmatic, it does not seek to manipulate people. At best, it liberates the spect-actors. At best, it stimulates them. At best, it transforms them into actors. Actor - he or she who acts.

Paterson (1994: 37) presents his observations of the discovery of Boal's Forum Theatre:

The breakthrough moment came when a woman in the audience said that the wife on stage, dominated by her husband, needed to have 'a very clear' discussion with him. The woman was so upset by the actors' apparent inability to do what she imagined that she walked onto the stage and showed what she meant - beating the husband/actor with a broom until he stopped abusing his wife.

In Forum Theatre, people from the community decide what the important issues are. Either people from the community, or actors from Boal's company then enact a dramatization of the specific issue. A 'joker' - or facilitator - then reminds the spectators, as the company performs a second time, that they are encouraged to enter the action - to become spect-actors.

The term 'applied theatre' as used in this pilot study draws upon the principles and traditions of Forum Theatre (Boal, 1992), community theatre, Theatre-for-Education, Theatre for Development (PLA Notes, 1997; Prentki, 1998), research-based theatre (Gray et al., 2000), ethnodrama (Mienczakowski, 1997) and performance of research findings (Paget, 1990). The multiplicity of media that can be used for any narrative - from the simplicity of someone standing in a space and telling a story, to the use of complex technology - replicates our diverse situations and has a wide variety of possible applications. If the majority of the theatre makers are drawn from the community it serves, the semblance of the product and the integrity will be promoted. The work will not patronize but will open up a series of questions, possibilities and even solutions. 


\section{Setting and methods}

The SASPI was a multidisciplinary study drawing on epidemiology, anthropology, public health, neurology, geography and psychology. Ethics permission was received from the Ethics Committee of the London School of Hygiene \& Tropical Medicine, England and the Committee on Human Subjects, University of the Witwatersrand, South Africa.

The aims of the SASPI were to explore the growing problem of cardiovascular disease in rural Africa, by exploring the prevalence of strokes, the identifiable risk factors, lay understandings of stroke and its causation, and the burden of stroke on households and the wider community.

This article focuses on the dissemination and validation of findings from the anthropological part of the study focusing on health beliefs and behaviour concerning symptoms of weakness down one side of the body or stroke-like symptoms. Data was gathered through rapid ethnographic assessment (REA) and participatory methods in six villages. The fieldworkers in the study team were members of the University/Medical Research Council Rural Public Health and Health Transitions Research Unit (also known as the Agincourt Unit) of the University of the Witwatersand. The Unit carries out a regular annual census update of all vital events that have occurred in the past year. The Unit has an ongoing annual programme of community feedback meetings within which census and project-linked research findings are disseminated in a formal way. In addition to taking part in this existing programme of dissemination, the SASPI research team wanted to validate their findings and use a more interactive method of dissemination. In the six villages where the team had worked intensively with residents, it was decided to use an applied theatre approach.

The study was conducted in the rural Agincourt sub-district of Bohlabelo District, South Africa. This border region of northeastern South Africa was part of the homeland of Gazankulu during the apartheid era. The process of forced villagization occurred in the 1960s. Agincourt comprises 21 villages and has a population of some 70,000. Close to a third of the population are self-settled former Mozambican refugees who migrated to Agincourt during the civil war in Mozambique in the 1970s and 1980s. The inhabitants are largely the Shangaan people.

In the part of the SASPI study reported here, households were asked what they thought the important health issues in their villages were, their beliefs about weakness down one side of the body, their health-seeking behaviour and the impact of stroke on the household. REA and participatory diagramming and visualization were used with 105 households and with group interviews. Thirty-five stroke survivors participated in in-depth interviews.

Informed consent was requested at the community and individual levels. First the induna (headman) in each village was approached and he then called a village meeting. Three local fieldworkers (PR, RM and EM) 
explained the study aims and requested permission to work in the village. Once permission was granted, written consent was requested from individual interviewees. These same fieldworkers participated in the development and performance of applied theatre.

The REA took place between March and October 2002. REA uses a range of ethnographic and qualitative research methods to gain a contextual understanding of community beliefs and explanations of health. It is similar in approach to rapid appraisal techniques and uses methods of ethnography - participant observation, individual interviews, and focus groups selected through snowballing.

Participatory techniques of village mapping, illness ranking and listing of sources of care were conducted at this meeting and followed by health walks with individuals around the village. Subsequently, individual and natural group interviews were held with a wide range of people. The groups included football teams, care groups, burial societies, saving societies, healers, church members and gardening groups. The individuals included older and younger women and men, prophets, inyangas (healers), pastors, shop owners and teachers. In addition, interviews were held with some private doctors and nurses at the clinics. The interviews were conducted in Shangaan and written up in extended notes in English by the fieldworkers.

The household interviews were conducted with 35 stroke sufferers and their main carers. They were identified through a screening question asked during the annual census update carried out by the Agincourt Unit, with subsequent confirmation of the diagnosis of stroke by a study physician (The SASPI Team, 2004a). The interviews were tape-recorded and translated and transcribed by the fieldworkers. All of these interviews were then analysed with the assistance of NVivo software by $\mathrm{GLH}^{1}$ and MS. The REA material was principally coded by MS and the household interviews by GLH. The coding nodes were checked for inter-reliability by several transcripts being coded independently by both GLH and MS and then being compared.

\section{Xiseveseve (coming together to share)}

The research team decided to adopt applied theatre in order to address the following aims. First, to validate research findings. Second, to deepen understanding about where and how to get better support, care and management of stroke-like symptoms. Third, to provide local people with the opportunity to voice (as in forum theatre) possible models of community interventions.

\section{Key findings from SASPI for dissemination and validation through applied theatre}

Drawing largely on Boal's Forum Theatre, the principles of participatory research and of ethnography, applied theatre was used to disseminate results on three SASPI study topics: social context of health, plural understandings of health, illness and stroke and health-seeking behaviour. 
Social context of health In looking at community perspectives of health and illness, people were asked about what they thought their important health issues were. People related health to livelihood issues of water, electricity, food and employment. In this community, as with other rural South African communities, it was found that there is a mixed household economy of formal and informal paid work, unpaid work and social care grants. The latter - including pensions, child grants, foster care grants and disability grants - are often the most reliable income source for households. The diversified livelihood systems that influence health are gendered, generational and multi-spatial, and reflect access to political capital (Stuttaford, Lewando Hundt and Ngoma, 2004).

Plural understandings of health, illness and stroke The SASPI study also aimed to answer the questions: what are the lay understandings of strokelike symptoms and what are the health-seeking behaviours of residents in the Agincourt area? The main findings were that health and ill-health are considered to be both physical and social in origin and as a result plural healing - using both clinical and social diagnostics - are sought. Most people maintain their physical, mental and social well-being and deal with ill-health by visiting both doctors and healers, prophets and churches (The SASPI Team, 2004b, 2004c).

Who bears the burden of stroke? The final aspect of the SASPI study to be disseminated using applied theatre looked at how households cope with the burden of disability and illness. Stroke is a sudden event that alters the lives of the stroke sufferer and their household irrevocably, and for the most vulnerable this can be catastrophic. It was found that individual and household vulnerability is ameliorated to a limited extent by accessing social and financial capital.

The impact of misfortune is also mediated by strategies that involve being cared for by family members, social networks and associations, and healers, prophets and churches. Although public clinics and hospitals, and private doctors, offer care during the acute phase immediately following the onset of stroke, the household members, healers, prophets and churches handle chronic management. Very few stroke survivors were using biomedical means of secondary prevention, such as aspirin or taking anti-hypertensive medication (The SASPI Team, 2004c).

\section{An outline of the development of the applied theatre Xiseveseve}

MS and GLH were based in England and were familiar with the SASPI study and setting, MS as a research fellow and GLH as a co-investigator. When it was decided to use applied theatre, CB joined the team with her expertise in applied theatre. Through CB, the research team learnt about this approach and she provided practical training and theoretical guidance. MS then visited the field site, with: the practical skills gained from $\mathrm{CB}$, a 
rough idea of several actions and an outline of the key findings the research team wanted to disseminate and validate. Over two weeks, working together in a community centre in Agincourt, MS, BN, RM, PR and EM developed and performed the actions for Xiseveseve. The local knowledge of RM, PR and EM as residents, together with what they had learnt from the data collection, as fieldworkers, was vital in working out appropriate forms of presentation of the findings.

Due to issues of confidentiality, no one particular 'typical' case was presented. Nor were direct excerpts from interview transcripts used to create a formal script. Rather, the data analysis and familiarity with the data led to the development of a composite picture of the three themes. There were several ethical questions that were debated and these were generic to this approach. These include: the extent to which direct excerpts can be used from transcripts without breaking participant confidentiality; who should develop and facilitate the theatre; and how to portray practice the researchers are concerned about re-enforcing. For example, in Xiseveseve, the SASPI research found that few people were using secondary prevention measures. This was for a multiplicity of reasons. In order to stay true to the findings this had to be depicted but with theatre often being used for health promotion purposes, the research team were concerned the spect-actors would misinterpret the portrayal as condoning such practice. This was therefore addressed in the fact sheet handed out at the end of the actions. However, the research team need not have worried: without fail, a spect-actor intervened to say that the protagonist should comply with his treatment.

The protagonist was the afflicted - the man who fell down while working in his fields and experienced stroke-like symptoms (EM), or 'dryness', 'weakness down one side'. The afflicted were also the man's immediate family who became the main carers and made decisions in a context of poverty and the loss of the household's main income earner (RM and PR). The second role was that of the 'joker' who directed questions to the audience and sought their participation (RM). Third, was the 'provider' of health care - clinic nurse, hospital doctor, inyanga and prophet (PR). Fourth, was a 'scribe' to take notes of interactions with spect-actors (BN). The role of the scribe was vital for documenting audience responses. The fifth role was the 'spect-actors', or the 'audience' - who, through the joker, became the voice of the afflicted's extended family.

The four fieldworkers were all well known by the local communities from having conducted the fieldwork and through being residents in Agincourt sub-district. They arranged times and places to perform the applied theatre through community channels established during the data collection phase of SASPI. Xiseveseve was facilitated six times to groups of various sizes (from 30 to 100 people) Group size varied because, in one village, it was performed prior to a village meeting to discuss other issues. The location was mainly outside under a tree, using minimal props. For example, PR 
simply wrapped different coloured cloth around his shoulders to depict his change in roles.

Once people were gathered, PR (who had always acted as the spokesperson at community meetings) briefly introduced the team; they then went into role and performed the following eight actions: prologue introducing the characters, hoeing the field, visit to clinic, visit to hospital, home, visit to inyanga, home, fetching from inyanga and going home, visit to prophet.

The spect-actors or afflicted's extended family were invited to participate by, for example, joining the carers and afflicted on the grass mats depicting a 'stage' and participated in deciding where to take the man for care and in discussions about what might have caused this to happen. The 'script' was loosely agreed and was flexible in order to be responsive to the decisions made by the extended family. The eight actions did not always happen in the same order and the spect-actors decided where the afflicted should go next. The joker would turn to the spect-actors and say: 'My family, what shall we do?' The spect-actors would then make a collective decision.

The spect-actors were spontaneously active in the theatre. For example, at one performance spect-actors assisted the afflicted into the wheelbarrow used for depicting going between sources of care (Figure 1) and, at another performance, a spect-actor got up and kicked the afflicted saying the reason he had fallen down was because he was lazy. Spect-actors also participated by singing, clapping and responding to the chants of the inyanga.

At the end of the actions, the fieldworkers returned to their researcher roles and asked the spect-actors what they thought of the portrayal of

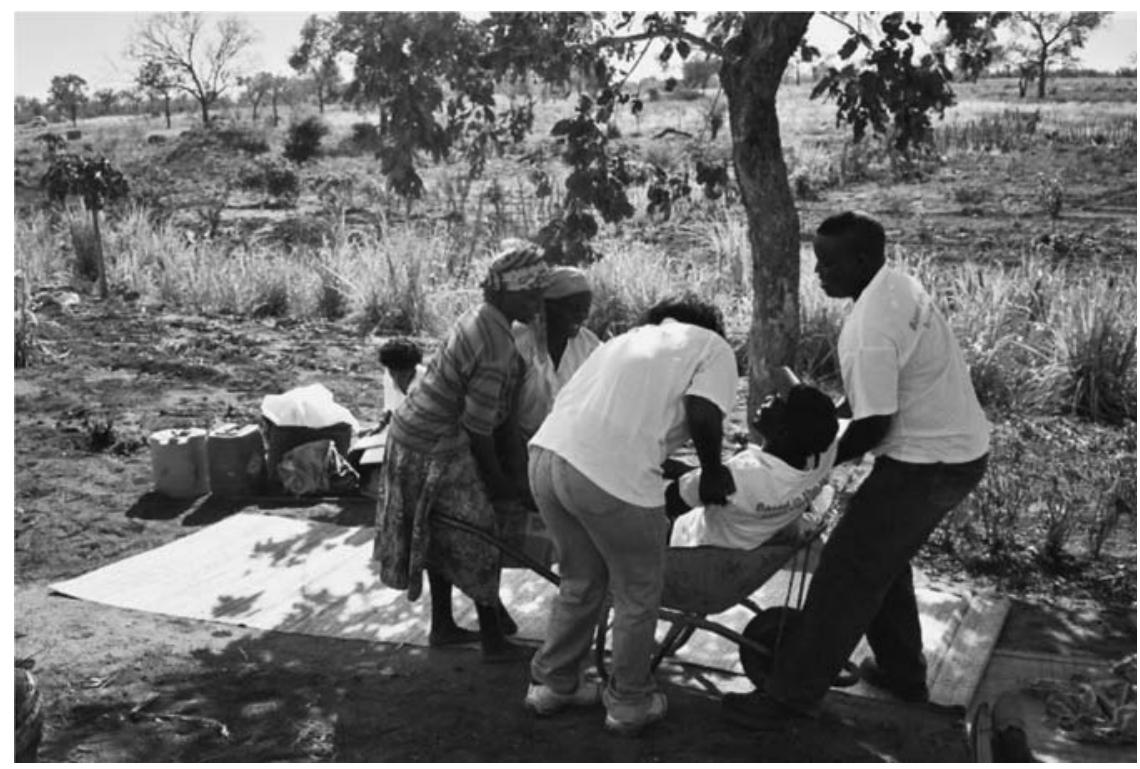

Figure 1 Spect-actors assist the afflicted into a wheelbarrow. 
'dryness' and also if they had any ideas for future interventions. A factsheet was handed out in answer to questions about accessing the disability grant and about treatment for high blood pressure. These factsheets had been prepared in conjunction with other members of the SASPI team (MC and MT) to ensure accuracy of medical advice. If any questions arose that could not be answered by the fieldworkers, spect-actors were advised to ask at the clinic or to ask social workers.

At all six performances, the spect-actors said that the portrayal of family decision-making and plural healing was accurate. In addition to data validation and dissemination of findings, at the end of the actions, the spectactors were asked about possible future directions for similar health research. During the discussions about potential future interventions several themes emerged. First, were issues related to the wider context, for example addressing poverty. Second, strengthening the clinic-based services, for example health checkups at clinics, having a clinic in the community, buildings for respite care and education, education regarding continuation of blood pressure tablets. Third, services in the community, for example community physiotherapists, home visits and social workers to help with accessing benefits. Fourth, building on existing strategies and services as well as new ways of working; for example, hospitals and inyangas should work together, and researchers should work with the local clinics. Fifth, household and community support, for example support from family members and physical help from community groups.

On reflection the fieldworkers said:

At first I thought this was peripheral to the study. But when we began to perform, I was amazed at how passionate people were about the situations and views we acted for them. It became clear that our findings were indeed part of their lives. (EM)

This was a different form of feedback not like a conventional presentation. People found it interesting and they became part of the story with their views and were involved. (RM)

\section{Conclusions}

The use of applied theatre for the validation and dissemination of health research findings in the SASPI project was done as a small-scale pilot to assess if this approach was feasible for validating and disseminating data and for eliciting views concerning possible next steps in the management of cardiovascular disease and its associated problems. It did not set out to achieve the targeted social change of Forum Theatre, but it did employ principles of ethnotheatre. It was also community theatre in that it used nonprofessional actors, residents of Agincourt, in a community space. It was found that for validating data and for dissemination, applied theatre worked better in smaller community groups, in that it allowed greater opportunities 
for eliciting views. It also complemented other validity checks such as prolonged engagement of the team in the setting, ongoing observation, debriefing with peers and triangulation of methods and data sources.

The aim was not that of Forum Theatre in the sense of 'liberation' as described by Boal in that the spect-actor frees him-/herself from oppression and acts for him-/herself. The aims of the theatre makers were to validate data; the heightened sense of catharsis of the audience was justification for this. Strategies of Forum Theatre were used to engage the audience and thus provide a context - that of the extended family for the participatory element. The success of the participatory outcome was embodied in the understanding that theatre and story telling within African culture brings with it an expectation of response and active engagement.

Every theatre company knowingly or unknowingly uses ideas that have been developed by other practitioners. These ideas may not be used wholesale but adapted and re-invented by theatre artists to suit particular situations. In the SASPI project it was appropriate to position the audience as the extended family of the protagonist and invite their counsel through the drama. It was important to leave the text to be improvised by the fieldworker/players within a pre-written framework in order to accommodate the suggestions from the audience. The fieldworkers and the researchers themselves made the theatre; thus the theatre can be described as ethnotheatre or ethnographic performance, though it is also community theatre as it is performed by non-professional actors in a community setting (under a tree in a central part of the village).

The use of applied theatre could be further developed in this area drawing on existing practices. There is a tradition of story telling and performance in the wider Bohlabelo District: for example, the muchongolo dance, performed mainly by male dancers and female singers who sing about AIDS/HIV, the economy of the country, religious issues, local personalities and other current or historical topics.

The applied theatre served several needs, both validating the research and empowering the community and the researchers with new and valuable insights into the project. Further research is required to develop methods for evaluating the impact of applied theatre as a method for both validating data and disseminating research findings. Theatre for Development and community theatre techniques are already sometimes used in the early stages of research and development initiatives that follow a participatory approach and this pilot has shown the usefulness for theatre in the validation and dissemination phase of research.

\section{Note}

1. Authorship contributions. The co-applicants of this multidisciplinary study, led by Margaret Thorogood, worked closely in the overall management of the SASPI Study. Gillian Lewando Hundt managed the anthropological components. Maria Stuttaford drafted this article, developed the participatory 


\section{Stuttaford et al.: Applied Theatre in Health Research Dissemination}

methodology and initiated the idea of using applied theatre, trained the field team in the participatory techniques and applied theatre, co-developed Xiseveseve and helped supervise data collection and carried out data analysis of the REA. Gillian Lewando Hundt developed the anthropological components of the study, trained and supervised the field team and analysed data and further developed the idea of using applied theatre and of Xiseveseve and contributed to the paper. Claudette Bryanston provided theoretical and practical guidance on the use of applied theatre, trained Stuttaford and Lewando Hundt and wrote parts of this paper. Bulelwa Ngoma managed the fieldwork and assisted in the performance of Xiseveseve. Regina Mathumbu and Patrick Rikhotso collected the data on which this paper is based and they, together with Elly Mokoena, co-developed and performed Xiseveseve. Margaret Thorogood, Stephen Tollman and Myles Connor have commented on earlier drafts of this manuscript and supported the piloting of this method of data validation and dissemination.

The SASPI team for this part of the study were (including their abbreviations as used in the body of the paper:

Professor Margaret Thorogood (MT), principal investigator*

Professor Stephen Tollman (ST), co-investigator**

Professor Gillian Lewando Hundt (GLH), co-investigator*

Dr Myles Connor (MC) - Senior Lecturer in Neurology, co-investigator**

Dr Maria Stuttaford (MS) - Lecturer in Human Geography***

Ms Bulelwa Ngoma (BN) - research fellow**

Ms Regina Mathumbu (RM) - senior fieldworker**

Mr Patrick Rikhotso (PR) - senior fieldworker**

Mr Elly Mokoena (EM) - senior fieldworker**

* University of Warwick, England

** University of the Witwatersrand, South Africa

*** University of St Andrews, Scotland

\section{References}

Boal, A. (1979). Theatre of the oppressed. London: Pluto Press.

Boal, A. (1992). Games for actors and non-actors, 2nd edn. London: Routledge.

Cornwall, A. (1997) Performance and participation: An overview. PLA Notes, 29, 23-9.

Fenn, C. (2003). Arts in Health - research findings (draft). London: Arts Council England.

Goldstein, T. (2001). Hong Kong, Canada: Playwriting as critical ethnography. Qualitative Inquiry, 7(3), 279-303.

Gray, R., Sinding, C., Ivonoffski, V., Fitch, M., Hampson, A. and Greenberg, M. (2000). The use of research-based theatre in a project related to metastatic breast cancer. Health Expectations, 3, 137-44.

Lincoln, Y.S. and Guba, E.G. (1985). Naturalistic inquiry. London: SAGE Publications.

Liebling, H. (2004). Ugandan women's experiences of violence, rape and torture during civil war years in Luwero District: Implications for health policy, welfare and human rights. Centre for Social Justice Annual Conference: Getting the Message Across: Social Justice in the Real World, 28 April 2004, Coventry. 
Making Research Count (2003). Trauma. A Geese Theatre Production commissioned by Making Research Count University of Warwick in association with Coventry University.

Malunga, F. (2002). Dance, ethnic differences and oppression: Instruments of labour and social control at the Messina copper mines, 1920-1960. Discourses on Difference and Oppression, University of Venda, 19-22 July. Available at: http://www.geocities.com/culdif/malunga.htm (accessed 16 April 2004).

Mienczakowski, J. (1997). Theatre of change. Research in Drama Education, 2(2), 159-72.

Mienczakowski, J., Smith, R. and Sinclair, M. (1996). On the road to catharsis: a theoretical framework for change. Qualitative Inquiry, 2, 4, 439-62.

Paget, M.A. (1990). Performing the text. Journal of Contemporary Ethnography, 19(1), 136-55.

Paterson, D.L. (1994). A role to play for the theatre of the oppressed. The Drama Review, 38(3), 37-49.

PLA (Participatory and Learning Action) Notes (1997). Performance and Participation. PLA Notes Special Issue, 29. London: IIED.

Prentki, T. (1998). Must the show go on? The case for Theatre for Development. Development in Practice, 8(4), 419-29.

Public Health News (2003). Special Edition. The Faculty of Public Health Annual Scientific Meeting, Thursday 26 June.

Saldaña, J. (1998). Ethical issues in an ethnographic performance text: The 'dramatic impact' of 'juicy stuff'. Research in Drama Education, 3(2), 181-96.

Saldaña, J. (2003). Dramatizing data: A primer. Qualitative Inquiry, 9(2), 218-36.

The SASPI Project Team. (2004a). 'Prevalence of stroke survivors in rural South Africa: Results from the Southern Africa Stroke Prevention Initiative (SASPI) Agincourt Field Site'. Stroke, 35, 627-32.

The SASPI Project Team (Gillian Lewando Hundt, Maria Stuttaford and Bulelwa Ngoma) (2004b). The social diagnostics of stroke-like symptoms: healers, doctors and prophets in Agincourt, Limpopo Province. South Africa, Journal of Biosocial Science, 36, 433-43.

The SASPI Project Team (2004c). Hypertension in stroke survivors and secondary prevention of stroke in a rural South African population: Results from the Southern Africa Stroke Prevention Initiative (SASPI) study, Agincourt Field Site, International Bulletin of the World Health Organization, 82(7), 479-558.

Stuttaford, M., Lewando Hundt, G. and Ngoma, B. (2004). Health and livelihood systems: gender, generation, space and political capital - findings from the SASPI study, conference presentation, International Society for Equity in Health, Durban, South Africa, 10-12 June.

The Drum Beat (2004). The Communication Initiative. Available at: http://www.comminit.com/healthcomm/ (accessed 5 August 2004).

The National Network for Arts in Health (2004). Available at: http://www.nnah.org.uk/ (accessed 5 August 2004).

\section{Author biographies}

MARIA STUTTAFORD is a lecturer in Human Geography in the School of Geography and Geosciences at the University of St Andrews. Her current research and teaching interests are in health as a human right and participatory research approaches. 
CLAUDETTE BRYANSTON is co-artistic director of Classworks Theatre, Cambridge, and holds a part-time Fellowship in Applied Theatre at the Institute of Health, University of Warwick.

GILlian LEWANDo HUNDT is Professor of Social Sciences and Director of the Institute of Health in the School of Health and Social Studies at the University of Warwick.

MYLES CONNOR is a senior lecturer in Neurology at the Medical School of the University of the Witwatersrand and Director of Neurology at Baragwanath Hospital, Soweto, Johannesburg.

MARgaret THOROgood is Professor of Epidemiology at the Warwick Medical School, University of Warwick.

Stephen tollman is Professor of Public Health, at the School of Public Health, University of the Witwatersrand. 